\title{
Revisiting Impurity in Republican China: An Evaluation of the Modern Rediscovery of Bujing guan 不淨觀
}

\author{
Ester Bianchi (D)
}

Citation: Bianchi, Ester. 2021. Revisiting Impurity in Republican China: An Evaluation of the Modern Rediscovery of Bujing guan 不淨觀. Religions 12: 903. https://doi.org/ $10.3390 /$ rel12100903

Academic Editor: Michel Mohr

Received: 11 August 2021

Accepted: 29 September 2021

Published: 19 October 2021

Publisher's Note: MDPI stays neutra with regard to jurisdictional claims in published maps and institutional affiliations.

Copyright: (c) 2021 by the author Licensee MDPI, Basel, Switzerland. This article is an open access article distributed under the terms and conditions of the Creative Commons Attribution (CC BY) license (https:// creativecommons.org/licenses/by/ $4.0 /)$.
Department of Philosophy, Social Sciences and Education, University of Perugia, 06123 Perugia, Italy; ester.bianchi@unipg.it

\begin{abstract}
During the era of the Republic of China, a number of Buddhists rediscovered early meditation techniques. These practices were mainly revived from canonical scriptures, following a modern text-based approach to Buddhism. Within this framework, specific attention was devoted to the 'visualization of the impure' (bujing guan 不淨觀, Sk. aśubhabhāvanāa), particularly in the form of the visualization of one's own body transforming into a putrefying corpse and skeleton. Masters with various backgrounds (Modernist Buddhists, Yogācāra scholars, Tiantai 天台 and tantric masters) wrote articles and guides on this practice, which had the advantage of being common to both Hīnayāna/Śrāvakayāna and Mahāyāna. This study considers a selection of modern texts on bujing guan in an attempt to uncover why the meditation on impurity was favored and how it was revived.
\end{abstract}

Keywords: bujing guan (aśubhabhāvanāa); meditation on impurity; aśubha meditation; modern Chinese Buddhism; early meditation techniques

\section{Introduction}

In the first half of the twentieth century, following the spread of modernist ideas, ${ }^{1}$ a rediscovery and reassessment of 'neglected' texts in the Chinese Buddhist canon took place in China. ${ }^{2}$ As part of a tendency of reevaluating the Buddha's 'original' teachings, forms of meditation found in the early Chinese scriptures were rediscovered and implemented, the general idea being that of reintegrating them within Chinese Mahāyāna. ${ }^{3}$

These 'forgotten' early meditation practices were conceived as fundamental meditative techniques that had the advantage of encompassing both the Hīnayāna/Śrāvakayāna ${ }^{4}$ and the Mahāyāna traditions. They were outlined not only in the Āgamas (Ahan jing 阿 含經) and other scriptures belonging to the 'Hīnayāna,' ${ }^{5}$ but also in relevant Mahāyāna texts, such as the Yogācārabhūmi (Yuqie shidi lun 瑜伽師地論, T no. 1579) and particularly the fourth chapter on 'Foundation on Meditative Absorption' (Samāhitā bhūmi) ${ }^{6}$ as well as the Dazhidu lun 大智度論 (Treatise on the Mahāprajñāpāramitāsūtra, T no. 1509) and in meditation manuals and essays on meditation techniques composed by pre-Chan 禪 masters. ${ }^{7}$ The prominent reformist monk Taixu 太虛 (1890-1947), for example, stated that 'Zhiyi 智顗 [538-597]'s “Exposition on the Perfection of Dhyāna" [Shi chan boluomi cidi famen 釋禪波羅蜜次第法門, T no. 1916, which outlines these early practices in a systemized and coherent meditative path] was the most comprehensive work on meditation to circulate in China from the Han Dynasty all the way through to the end of the Northern and Southern Dynasties'. ${ }^{8}$

Among the rediscovered practices are the 'five gates of meditation' (wu menchan 五 門禪, or wu tingxin 五停心, 'five kinds of mental stabilization'), each of which is suited to practitioners with different temperaments. The five approaches include the visualization of the impure, meant for those who are inclined to lust (tanyu 貪欲, Sk. rāgacarita). ${ }^{9}$ Another set of meditation techniques which received great attention is the 'four sites for 
recollection' (si nianchu/zhu 四念處/住, Sk. catuhsmrtyupasthāna, Pāli cattāro satipaț̣̂āna), whose 'visualization of the body' (guan shen 觀身) includes a meditation on its impurities. ${ }^{10}$

The 'visualization of the impure' (bujing guan 不淨觀, Sk. aśubhabhāvanāa)—hereafter also referred to as 'meditation on impurity' or 'aśubha meditation'-implies the meditation on the impurities of the body and, in the form that became most relevant in modern times, it involves the meditative observation of the phases of one's own decaying corpse, up to the moment it transforms into a skeleton. ${ }^{11}$ In the recent years, the reception and development of this practice in medieval China has been investigated by a number of scholars, most of whom have focused in particular on pre-Chan meditation manuals and Tiantai works. ${ }^{12}$ A cursory glance at the occurrences of this practice in Chinese texts composed from the Song dynasty onward suggests that it was not completely abandoned after the advent of Chan. ${ }^{13}$ In fact, the practice resurfaced and spread widely among Buddhist practitioners in modern times, and it remains a prominent practice today. As with other early meditation techniques, the meditation on impurity is common both to Hīnayāna/Śrāvakayāna and Mahāyāna. It was particularly enjoined as a way to counter desire or lust, and-like other practices found in early texts—as a useful preliminary practice within the Mahāyāna path. ${ }^{14}$ The 'visualization of the impure' was implemented during the era of the Republic of China as an independent practice, as part of the 'five gates,' and as part of the 'contemplation of the body' within the 'four sites for recollection'.

The present study is an attempt to uncover why and how the meditation on impurity was favored and revived. First, it will introduce the practice in connection with Buddhist Modernism by analyzing its occurrence and significance in Taixu's works. Second, it will address the growing interest in visualization practices of impurity in the 1930s through a selection of texts penned by modern Chinese Buddhists of different inclinations (Yogāaāra, Tiantai 天台, and tantric). Finally, it will provide a close reading of a long essay on the topic by Taixu's disciple Tanxuan 談玄 (d.u.), which offers a detailed overview of the canonical literature on aśubha meditation available at the time and proves particularly telling with regard to the variety of the forms of the practice and of the different Buddhist groups involved in its implementation.

\section{Paving the Path: Taixu 太虛 and the Role of Buddhist Modernism}

In his essay titled 'The features of Chinese Buddhism lie in Dhyāna' (Zhongguo foxue tezhi zai chan 中國佛學特質在禪), a fundamental work for understanding the role of meditation within his system, Taixu distinguishes between 'tathägata chan' (rulaichan 如來 禪), i.e., meditative techniques received directly from the Buddha, and 'patriarchal chan' (zushichan 祖師禪), which refers to the form of meditation developed by the patriarchs of Chan Buddhism..$^{15}$ The former includes the 'five gates to meditation,' and thus aśubha meditation as a practice suitable for those who have a propensity toward lust (Taixu, 1943).

For Taixu, meditative techniques predating Chan (including aśubha meditation) were not meant to replace Chan practices. Rather, he was implementing them in order to return Buddhist meditation practices in China to a state of completeness. This attitude had already been expressed in one of his early lectures on 'The essentials of the Buddha vehicle, i.e., Pure Buddhadharma' (Fosheng zong yao lun. Chunzheng de fofa 佛乘宗要論一純正的佛 法), which was delivered in Guangzhou in 1921. In it, Taixu places aśubha meditation in the context of Hīnayāna practices, which aimed at 'having a comprehensive view of impermanence, suffering and emptiness, no-self, and impurity' (wuchang kukong wuwo bujing 無常苦空無我不淨), and are related to the 'four sites for recollection' (si nianzhu). ${ }^{16}$ Under the title 'One's own and others' bodies are all impure' (zita yiqie shen bujing 自他一 切身不淨), Taixu explains the notion of bujing/aśubha in a manner that echoes the relevant canonical texts. The description reads as follows:

Purity implies beauty. We are used to having this body, which we love without recognizing that it is ugly. But when seen from the Hinnayāna practice of recollection, there is nothing beautiful in it from start to end. At the very beginning, 
the body is formed in the womb from the union of the father's essence and the mother's blood; in this there is no purity or beauty that one can talk about. Neither is there any cleanliness or purity when the body comes into the world, leaving behind manure and dirt and shedding snot and urine. Then, when it grows up in good shape and glowing with health, it appears to be beautiful. However, when we examine it in detail, on the outside there is only sweat, dirt, and grease which do not vanish even if bathed, resulting in millions of microscopic insects continuingly gnawing at our skin day and night. On the inside, the five pungent roots and various other impurities are stored. Thus, neither in- nor outside is there anything pure and beautiful. This seemingly beautiful thing is only a bubble-like perceived object, self-defiled visual consciousness; let alone when one considers that the twilight of life approaches in the twinkling of an eye, and that this seemingly beautiful bubble cannot be held for long. At that point, blood and breath become weak and the vital spirit decreases, the hair greys, the teeth fall, the flesh becomes thin and the skin yellow, all kinds of diseases break out and there are signs that the four elements will soon dissipate. When the warmth and consciousness of a lifespan is over, first the color changes, followed by flesh and skin; then pus and blood mix and spread, and bones, muscles, and ashes are scattered. If there is something left, it surely is not pure or beautiful. This way we know that our material body is impure from the beginning of its existence down to its extinction. If we extend this from ourselves to others, we will see that the same is true for all of us. Thus, the dearly loved mundane material body, which does not halt to cause defilements and create evil karma, is really meaningless.

淨、是美好之義, 吾人習有此身, 固已愛而不知其惡。然以小乘正念觀之, 自始 至終無可美者。身之最始厥為住胎, 父精母血和合而成, 殆無淨美可言。及至 出世翼嵅時遺, 涕尿交流, 亦無潔淨。繼而長大, 體態端好, 容光煥發, 似可美 矣; 然而詳審諦視, 外則汗液垢淢沐浴不去, 坐令巨萬微虫書夜觢膚, 内則五 辛雜投葷濁備蓄, 自内而外, 無可淨美。其似可美者, 僅此泡影色塵, 自註眼 識, 而況惱人暮景轉瞬即至, 則並此似美之泡影, 不能久持。血氣内衰, 精神暗 損, 髮蒼齒落, 肌瘦膚黃, 百病叢生, 而有四大將散之兆矣。及至壽煖識盡, 顔 色先變, 肌膚次之, 膿血雜流, 筋骨灰散, 苟云有餘, 絶非淨美。是知吾人色 身, 從始有至於滅盡, 皆為不淨。推自及他無不皆然。而世之寶愛色身, 不惜自 起煩惱造作惡業者，誠無謂矣。(Taixu, 1921)

Aśubha meditation is again mentioned in the same text by (Taixu, 1921), always within the Hinnayāna section, as part of the 'thirty-seven practices for the attainment of enlightenment' (sanshiqi buti fen 三十七菩提分). ${ }^{17}$ The main aim of the text is that of reconciling Hīnayāna and Mahāyāna in the name of the 'true and pure Dharma.' In such a context, Taixu urges a reevaluation of the 'Hīnayāna' (xiaosheng 小乘)—defined as a conventional term for the two vehicles of the Śrāvakas and Pratyekabuddhas, which in turn should not be despised-together with its practices.

Other details about aśubha meditation are included in Taixu's lectures on particular canonical scriptures. For instance, in 1934 Taixu lectured on the 'Sūtra on the Eight Kinds of Attentiveness of Great Persons' (Foshuo ba da ren jue jing jiangji 佛説八大人覺經講記, $T$ no. 779), ${ }^{18}$ where aśubha meditation is part of the 'four sites for recollection' ${ }^{19}$ As for the Mahāyāna interpretation of the practice, it is worth mentioning Taixu's lecture on the 'Contemplation on the Mind Ground Sūtra' (Xindi guan jing 心地觀經, T no. 159), a text focused on Mahāyāna renunciants (i.e., Bodhisattva bhikșus). ${ }^{20}$ Aśubha meditation is presented in the seventh chapter on 'being disgusted with the body' (yan shen 厭身) as one of the practices common to the three vehicles (sansheng gong $f a$ 三乘共法). Featuring Maitreya as interlocutor of the Buddha, the chapter explains the various forms of aśubha meditation while also including the Mahāyāna approach, i.e., references to the body as empty, as well as to its preciousness as a means of carrying oneself and others to the other shore, and thus in connection with the Bodhisattva path. 
In short, Taixu's interest in the meditation on impurity does not imply any preference for the early meditation techniques, nor did he put any particular emphasis on aśubha meditation when compared to the other practices. However, it was precisely this modernist inclination of aiming for completeness in Buddhist practices that paved the way for its emergence as a favorite practice of some of the other masters.

\section{The Visualization of the Impure in Modern China}

A number of articles published in various Buddhist periodicals of the Republican era, particularly during the 1930s, suggests that there was a surge of interest in aśubha meditation at that time. These articles contain reprints of early canonical and extra-canonical texts, as well as new explanations and commentaries. This section offers an overview of these and other materials produced by a few relevant Republican Buddhist masters, focusing on a long article by Tanxuan.

\subsection{Practicing Bujing Guan in the 1930s: An Overview}

Considering the importance attached by Zhiyi to the early meditation techniques, it is not surprising to find modern Tiantai masters among the advocates of aśubha meditation. Xianming 顯明 (1917-2007), for instance, wrote an article supporting this practice as a way to counter desire and describing it as a fundamental technique that formed the basis of the four dhyānas (Xianming, 1936). As in the case of Taixu and other masters, Xianming highlights the universal nature of the practice, which is 'common to both Hīnayāna and Mahāyāna.' The article's title, 'On visualizing impurity to counter desire' (Bujing guan duizhi tanyu 不淨觀對治貪欲) is a possible quotation of Zhiyi's words (T no. 1915: 467b012). ${ }^{21}$ Xianming's article was published in the 31st issue of the Buddhist journal Hongfa kan 弘法刊 and was followed by an article by Zhaowu 照悟 (1936). The latter's title is a quotation of a common definition of the first of the 'five gates' (Duo tan zhongsheng bujing guan 多貪罚生不淨觀: ‘The visualization of the impure for the living beings that have a predominance of lust'). Using the practice as a way to counter desire is also described by Daqu 答劬 (1936), who presents details about its different forms, distinguishing between the visualization of one's own and another's impurity. The efficacy of the visualization of the impure to counter desire and its connection with the 'four sites for recollection' was further illustrated by the Yogācāra scholar Zhou Shujia 周叔迦 (1943).

A recurring theme in our texts is the visualization of the nine phases of the decomposition of a corpse, a sequence known as 'nine signs' (jiuxiang 九相, hereafter referred to as: 'nine images') or 'nine ideations' (jiuxiang 九想, Sk. navasamjjñ $\bar{a}$, hereafter referred to as: 'nine meditations'). ${ }^{22}$ It occurs in translations of relevant Indian scriptures, such as the Mahāprajūāpāramitāsūtra (Da bore boluomiduo jing 大般若波羅蜜多經, T no. 220.402: $7 \mathrm{~b} 24-26)^{23}$ and the Yogācārabhūmi (T no. 1579.25: 417b12-13). ${ }^{24}$ Similar sequences are also included in medieval meditation manuals, e.g., in Kumārajīva's 'Meditation Scripture' (Zuochan sanmei jing 坐禪三昧經, T no. 614: 271c12) ${ }^{25}$ and Zhiyi's 'Exposition on the Perfection of Dhyāna' (T no. 1916: 536a19-536c16). ${ }^{26}$ They also form the topic of the so-called 'diagrams of the nine meditations' (jiuxiang tu 九想圖), depicting a decaying corpse as an aid for the visualization. ${ }^{27}$

The sequence of the 'nine meditations' is at the core of the 'Ode on the visualization of the impure' (Bujing guan song 不淨觀頌) by the Qing master Shengyan 省庵 (1686-1734), which was significantly republished in the journal of the Hunan Lay Buddhist Society in 1934 , and was often quoted as a reference by modern Buddhists. ${ }^{28}$ With the exception of the sequence for the first five images, Shengyan's version maps onto the above quoted list of Zhiyi; it reads: 1. 'Swelling' (zhang xiang 脹想), 2. 'Bluish stasis of blood' (qingyu xiang 青瘀想), 3. 'Decaying' (huai xiang 壞想), 4. 'Besmearing of blood' (xuetu xiang 血塗 想), 5. 'Pus and decomposition' (nonglan xiang 膿爛想), 6. 'Being devoured' (han xiang 噉想), 7. 'Scattering' (san xiang 散想), 8. 'Bones' (gu xiang 骨想), and 9. 'Burning' (shao xiang 燒想) (X no. 1179, 256b04-257a12). Comparable verses were published two years later in Haichaoyin 海潮音 by Fazhi 法智 (1938) under the title 'Ode on the sequence of the 
nine meditations of the visualization of the impure' (Bujing guan jiuxiang guan cidi song 不淨觀九想觀次第頌). The latter list matches the 'Nine meditations to destroy lust' (po yinyu jiuxiang guan 破淫欲九想觀) published in 1927 by the well-known Pure Land master Yinguang 印光 (1862-1940), a version derived from the late-Qing 'morality book' Bu ke lu 不可錄 (What cannot be recorded) ${ }^{29}$ and destined to be very influential throughout the twentieth century. ${ }^{30}$ That list proceeds as follows: 1. 'Just diseased (xinsi xiang 新死想), 2. ‘Bluish stasis of blood' (qingyu xiang), 3 ‘Pus and blood' (nong xue xiang 膿血想), 4. ‘Dark reddish juice' (jiangzhi xiang 綘汁想), 5. 'Devouring worms' (chong dan xiang 蟲啖想), 6. 'Coiling tendons' (jinchan xiang 筋纏想), 7. 'Scattering of the bones' (gusan xiang 骨散想), 8. 'Scorched' (shaojiao xiang 燒焦想), 9. 'Dry bones' (kugu xiang 枯骨想). A combination of the description of the nine images in the Bu ke le and in Shengyan's text is reported in Tanxuan's essay and is translated below (Section 3.2).

The 'nine meditations of the visualization of the impure' (bujing guan jiuxiang 不淨觀 九想)—followed by a meditation on the skeleton emitting light—were also taught in the 1930s by the tantric master Nenghai 能海 (1886-1967), who integrated the meditation on impurity into his handbook for basic meditation. ${ }^{31}$ I will delve into this particular case as an example of the actual practice of the visualization of the impure in modern times. The aśubha meditation is part of a series of visualizations within a sequential meditative path; it is typically introduced by the 'meditation on death' (sixiang 死想) and is followed by the 'meditation on the white bones' (baigu xiang 白骨想). The meditation on death reads:

Visualize your body while it is cooling down and the vital energy is receding; the body becomes rigid: it is a corpse now.

觀想自身，身冷氣絶，肢體僵直，現前便是一具死屍。(Nenghai, 1946)

The nine meditations are listed as follows: 1 . 'Swelling' (pang 膀); 2. 'Tumefaction' (zhang 脹); 3. 'Blue [stains]' (qing 青); 4. 'Stasis of blood' ( $y u$ 瘀); 5. 'Decay' (huai 壞); 6. 'Spread of blood' (xuetu 血塗); 7. 'Pus' (nong 膿); 8. 'Decomposition' (lan 爛); 9. 'Maggots' ( $q u$ 蛽). While this list does not perfectly match any of the extant canonical lists, the explanation of the nine meditations closely follows the contents of the above quoted texts. $^{32}$ At the same time, by referring to the Chinese heroes Liu Bang 劉邦 (256-195 BCE) and Xiang Yu 項羽 (232-202 BCE) or to a modern object such as a light bulb, Nenghai adds a personal touch to the received tradition:

Visualize one's body as if deceased for a few days, as it slowly degenerates and smells bad. Initially, the skin becomes purple and starts to swell and bloat; after a while, blue stains begin to appear until blood comes out and the whole body assumes a dark purple color. The skin starts to decay and rot, and bad blood colors the whole skeleton. Dead blood becomes pus, while the flesh and the internal organs decompose, falling to pieces. Among the blood and the rotten flesh, worms are born; they crawl around and eat the remaining flesh. When they are done, they transform into moths and fly far away (this type of visualization is helpful in case of diseases; one can visualize worms eating at the bruises by concentrating on the areas of sickness). The body is now just a white skeleton. Next, visualize relatives and friends also as skeletons. If Liu Bang's and Xiang Yu's bones could be together, do you think they would still be at war with each other? The conflicts between us and our enemies are certainly not as serious as those between the two generals: if we all become skeletons [in the end], why should we fight [now]?

觀想自身死已數日, 漸漸變壞, 如聞臭穢之氣。初皮膚變紫；次肌肉腫脹；次一 處一處變青色; 次一處一處惡血浸出成紫黑色; 次皮肉壞爛; 次壞血塗滿骨骼 之上; 次血腐成膿 ; 次見肌肉藏腑潰爛, 一塊一塊, 脱落地上; 次見壞爛血肉盡 生蛆蟲, 遍身鑽吃, 將腐肉食盡, 化為飛蛾飛去不見. 修此觀者, 能愈疾病。如 身生瘡者, 想患處為蟲所食, 病即易愈。自己觀成白骨。復觀自己平時所愛之 人，畢竟亦成白骨，貪欲自息。或有平時蓄恨之人，觀彼與我畢竟皆成白骨，嗔 心自息。試將劉邦項羽白骨置於一處, 試觀其復能鬥爭否。我與我之仇怨, 勢 
力及所爭, 均不如劉邦項羽, 亦復皆成白骨, 尚何爭競之有。（若不能觀全身 者，散亂重者，應從足大趾上指許大一塊觀起 ; 昏沉重者 , 應從額際指許大一塊 觀起，漸及全身）。(Nenghai, 1946)

At this point comes the visualization of the 'white bones emitting light' (baigu liuguang xiang 白骨流光想), the title of which is a quotation derived from canonical material (e.g., Zhiyi's T no. 1916: 500b08-09):

Concentrate on your body, now a skeleton, and recognize that passions, desire, and rage vanish. Visualize the skeleton: every single part of it emits a soft white light, similar to pure jade. Inside each bone there is a flaming red string like the incandescent string in a light bulb. Gradually the light is projected toward the outside, and a sphere of pure white light embraces the body. (The dimensions of the sphere depend on each practitioner's experience. Beginners visualize the diameter of the sphere with the length of their arm. During each new practice, the sphere gradually spreads out until it embraces the whole universe. The growth of the sphere follows certain parameters: each time, the sphere increases by an arm's length. It gradually holds a room, a palace, a village, a city, a state, a continent, etc. If the process were not gradual, it would become impossible to project the light to embrace the entire universe: one would not be able to increase its size. This type of meditation can cure bone diseases and reinforce the bone structure). 思維自身已成白骨, 粗大之貪嗔悉皆止息。然後觀想自身骨節, 一一潔白光 瑩, 如白玉所成。一一骨骼之中心, 各有一紅線, 放出光明, 如電燈泡中之鐵 絲。光明射出白骨之外, 籠罩全身, 成一白光團。初時前後左右上下各一舒手遠

(即使其光成一半徑一舒手遠之球形是）。以後每次修觀逐漸加大, 乃至遍於三 千大千世界。放光加大之法, 要有一定界限。譬如一舒手遠, 次加至滿一室, 次 加至滿一屋宇, 次一村一邑一國一洲等。若不如是漸加, 徒想遍於三千大千世 界, 實則心力仍只能及於極小之範圍也。如是觀者, 能治骨骼中病, 能使骨力强 健 。(Nenghai, 1946)

In Nenghai's meditation sequence, one then focuses on the red string inside the bones, the light slowly turning into white flesh, which evolves into the reappearance of the body as a young and healthy sixteen-year-old. This is the transformation of oneself into Mañjuśrī, which is part of tantric deity yoga and has no further relevance to our topic (Bianchi 2001, pp. 149-50).

The growing interest in visualization of impurity practices during the 1930s is well documented in a long and learned article by Tanxuan, who promotes the visualization of the impure among his contemporaries and, in an attempt to legitimize it, traces occurrences of this practice throughout the Buddhist Canon (from ÂAamas and Abhidharma to Mahāyāna scriptures and more recent Chinese texts). The following is an in-depth analysis of this relevant source.

\subsection{Tanxuan 談玄's Essay on the Visualization of the Impure}

This article by Tanxuan, who had studied Esoteric Buddhism in Japan ${ }^{33}$ and later enrolled in the World Buddhist Academy (Shijie foxueyuan 世界佛學苑) founded by Taixu in Wuhan, was published in 1936 by the Wuchang Academy (Wuchang foxueyuan 武昌佛 學院). It is addressed to Buddhist renunciants as a guide on how to work with this useful tool to counter sensual desire (aiyu 愛欲):

For those who leave home to pursue the path, the visualization of the impure is the best way to counter desire. If one succeeds in this visualization, all female appearances resembling jade or flowers will come to be a leather bags full of dirt. You should know that those white lotus faces are nothing but skulls covered with flesh and that beautiful young ladies are only leaking toilets dressed up with clothes. Is there anything to crave that one can talk about? I will thus describe the visualization of the impure on the basis of the sacred scriptures. 
出家學道對治貪欲,修不淨觀,第一良方。此觀若成,疑?對如玉如花之貌,全成革囊 聚穢之物。須知芙蓉百面,盡是帶肉骷髏, 美貌紅妝,也不過裝衣漏?,有何貪愛之可 言哉!是故依?聖言量,述不淨觀。(Tanxuan, 1936, p. 36)

After this preliminary statement about the practice's target and objectives, Tanxuan explains the 'name of the practice' by making a distinction between two different forms. The meditation on one's own bodily impurities (zixiangjing 自相境) includes a description of the visualization of the seven types of impurities, i.e., impurity of the seed, of parental intercourse, of the womb, of maternal blood, of birth, of the body covered by a thin skin and full of pus and blood, and of one's own corpse, which is quoted nearly verbatim, without referencing it, from Zhiyi's Jingtu shiyi lun 淨土十疑論 (T no. 1961: 80c14-23). On the impurities of one's own body, Tanxuan also quotes the Prajūāpāramitāsūtra ${ }^{34}$ and the Dazhidu lun. ${ }^{35}$ The second form is the contemplation of the common impurities (gongxiangjing 共相境); it consists in extending the awareness of one's own impurities to the external world, and is presented through a long quotation from the Sarvāstivāda Abhidharma. ${ }^{36}$ The examples mainly refer to the contemplation of the impurities of the internal parts of a living body; in the following, however, Tanxuan focuses more on the visualization of a decaying corpse. ${ }^{37}$

In the third part of the article, Tanxuan offers an interesting 'brief history of the visualization of the impure,' meant to give evidence of its orthodox origins. Tanxuan takes us back to the scene of Buddha Śākyamuni under the bodhi tree as he was tempted by 'beautiful ladies' sent to him in order to test his determination (unreferenced quotation from the 'Sūtra in Forty-two Sections,' Sishierzhang jing 四十二章經, T no. 784: 723b08-10). This is followed by quotations from texts focused on the same event that include descriptions of the filthy and impure bodies of the daughters of Māra, ${ }^{38}$ a reminder of the fact that the main objective of the practice is that of helping renunciants to counter sensual desire. The focus then turns to the scene of the Buddha in Vaiśālì, urging the bhikṣus to practice aśubha meditation by visualizing one's own decomposing corpse (unreferenced quotation from the Vinaya of the Mahīsāsaka, T no. 1421: 7a27-b03), and other accounts of the Buddha teaching aśubha meditation taken from the same vinaya text ${ }^{39}$ and from the Śüramgama. The latter is one of the first Mahāyāna scriptures to appear in the article, and it serves to connect the practice with the doctrine of emptiness. As evidence of the enduring nature of the practice over the centuries, Tanxuan then quotes a commentary on the Ekōttarāgama ( $T$ no. 1507.25: 40b06-15) that deals with Aśoka's brother meditating in a cemetery. ${ }^{40}$

The fourth part of the article explains the three different ways of practicing the visualization of the corpse in a cemetery according to the Mahāvibhasșa, ${ }^{41}$ namely the abridged practice for beginners, the extended practice for mature practitioners, and a third form of practice for expert practitioners. The text is reported almost verbatim from the canonical text ( $T$ no. 1545: 205b13-c18). Using another quotation from the same text ( $T$ no. 1545: 840a26-b10), Tanxuan explains that this practice is called 'common visualization' (gongxiangguan 共相觀) because it is common to the two vehicles as well as to male and female practitioners.

The fifth section, devoted to 'diverse visualizations' (biexiangguan 別相觀), introduces a concern regarding gender distinction in the practice. The 'visualization of the impure for men to counter women' (nan dui nü zhi bujing guan 男對女之不淨觀) begins with a quotation from the 'Scripture on the Methods of Censuring Sexual Desire' (He seyu fa jing 訶色欲法經, T no. 615: 0286a19-21, and 286a29-b01) describing women as obstacles to the practice, followed by the unreferenced quotation of Daoxuan 道宣 (596-667)'s description of the 'ten evils of women' and admonition to keep them at a distance in order to purify one's mind (T no. 1893: 824a12-c02). ${ }^{42}$ Finally, the impurity of a woman's body is described by means of other quotations, such as a passage from a dhāraṇisutra on the five types of bugs concealed in a woman's body, ${ }^{43}$ and a discussion on the overall impurity of a female body from a meditation manual titled 'Scripture on the Secrets of Meditation' (Chan miyao jing 禪祕要經). ${ }^{4}$ 
The 'visualization of the impure for women to counter men' (nü dui nan zhi bujing guan 女對男之不淨觀) begins with the common saying, 'Beautiful ladies are surely impure; how then could all men be pure?' (hongfenjiaren, gu duo bujing, yiqie nanren, you he jing $h u$ 紅粉佳人,固多不淨，一切男人,又何淨乎?) (Tanxuan, 1936, p. 41). Men as well, Tanxuan tells us, are nothing but skulls covered with flesh, living ghosts with stiff corpses. Thus, as with women, also in the case of men there is no beauty to speak of. As evidence for this saying, Tanxuan quotes the 'Sūtra of the Mātanga Girl' (Modengnü jing 摩鄧女經, $T$ no. 551: 0895b23-c02), featuring a dialogue between the Buddha and this girl, who was in love with Ānanda, and whom the Buddha showed the impurities (tears, mucus, saliva, faces, and urine, etc.) in Ānanda's body ${ }^{45}$ Finally, a relevant passage from the 'Scripture on the Secrets of Meditation' is quoted, reinforcing the idea of the many impure and polluted substances in a man's body ( $T$ no. $620: 335$ c20-336a02). ${ }^{46}$

The sixth part of the article addresses the method of the practice (bujing guan zhi xiufa 不淨觀之修法):

When practicing the visualization of the impure, one may go to a cemetery, or sit under a tree, or in a pure abode. Sitting cross-legged, one enters into correct contemplation, proceeding from the visualization of a just deceased corpse to that of white bones. One gets familiar with the practice and clearly distinguishes the objects of the sequence till there is nothing left but the white bones, at which point the visualization changes. One may visualize flesh growing on the white bones, or light emitting from the white bones, or may blow a breath of air so as to crush the white bones. One may also set the fire of the syllable $r a$ alight and burn out one's bodily impurity. ${ }^{47}$ The variations of this visualization practice have no limit.

修不淨觀時,或趣塚間,或坐樹下,或於淨室。跏跌而坐,入正思惟,自新死觀,至白骨 觀。次第熟練,了了分明,除白骨外，一無所有，至此轉觀;或觀白骨生肌,或觀白骨放 光,或自吹氣一口,白骨粉碎。或起囉字之火,燒熒?自身不淨,變化修觀,亦無窮矣。

(Tanxuan, 1936, p. 42)

This gives us an idea of the ways the visualization of the impure was being practiced during Tanxuan's time. First of all, it points to forms of imaginative visualization of the corpse under a tree or inside a Buddhist abode, such as had become common in medieval China (Greene 2021b, 27). Reference to the practice by means of an actual corpse in a cemetery may simply mirror the contents of early texts, since to my knowledge there is no evidence of aśubha meditation being practiced in cemeteries in Republican China. On a speculative basis, one could also hypothesize an awareness of the performance of the practice on charnel grounds by Tibetan practitioners, at a time when the spread of Tibetan Buddhism in China was at its apex (e.g., see Chen 2008). Second, the visualization of the white bones is described according to different variations and seemingly also includes a reference to a tantric version of the practice (i.e., the focus on the syllable $r a$ ), which Tanxuan may have encountered during his esoteric training in Japan.

This short but significant paragraph is followed by a detailed description of the images to visualize. Interestingly, for what seems to be the highlight of his article, Tanxuan combines the version found in the late-Qing 'morality book' $B u k e l u$, which had been republished a decade earlier by Yinguang, and Qing dynasty master Shengyan's verses in the 'Ode on the visualization of the impure.' Tanxuan reports, nearly verbatim, the whole sequence from the Bu ke $l u$, introduced by wei 謂 but without referencing it, while he openly references Shengyan's ode (but only includes eight images of the latter's sequence, omitting the fourth image, and adding the meditation on the moment of death, which in Shengyan's original is not part of the sequence). This combination of the two pre-modern descriptions of the 'nine images' reads as follows: ${ }^{48}$

1. Visualize the image of a newly diseased. [Bu ke de, 1]: Meditate (jingguan 靜 觀) on a person who has just died, lying stiff on the back, cold air piercing to the bones, not knowing anything. You should observe that your greedy and 
luxurious body in the future will also be like this. Hence lust will naturally fade away. Master Shengyan's verses [0] read: What is loved eventually leaves forever; it is so miserable that one cannot bear to behold it. Consciousness leaves the body and the corpse is already in the empty coffin! The night fire in the unoccupied hall is cold, the autumn wind blows on the mourning curtain: I advise you, Sir, while still alive, to meditate on the moment of death.

觀新死想。(1)謂靜觀初死之人,正直仰臥,寒氣徹骨,一無所知,當觀我貪財變色之 身,將來亦必如是,則婬心自然淡矣。(0)省庵法師頌曰: 《所愛竟長別, 淒涼不忍看; 識 裁離故體, 尸已下空棺!夜火堂冷,秋風素幔寒:勸君身在日,先作死時觀》。

2. Visualize the image of bluish stasis of blood. [Bu ke de, 2]: Meditate on a corpse not yet prepared for burial; within a week, black fluids rise and overflow, and it turns into dark purple, really fearsome. You should recollect that your own body, as beautiful as flowers, in the future will also be like this. Hence lust will fade away. Shengyan's verses [2] read: Long blows the wind, and the sun burns blue and yellow-how pitiful; the skin dries like an orange when it begins to rot, and the bones decay like half-withered beams. Ears are gone while the nose is still there, tendons and bones are broken and yet joined; a petrified person who does not talk: for all this, shed your tears!

觀青㾉想。(2)謂靜觀未斂骸死,一日至七日, 黑氣騰溢, 轉成青紫, 甚可畏 懼。當念我如花美貌之身, 將來亦必如是, 則婬心淡矣。(2)省庵頌日: : 風日久 吹多, 青黃殊可憐; 皮乾初爛橘, 骨朽半枯椽。耳鼻缺還在,筋骸斷復連; 石人雖不 語:對此亦淅然!»。

3. Visualize the image of pus and blood. [Bu ke de, 3]: Meditate on a dead person, first the rotten flesh decays into pus, which is about to break through, while intestines and stomach erode. You should recollect that your graceful and elegant body in the future will also be like this. Hence lust will fade away. Shengyan's verses [1] read: Drums within the wind, in a flash the swelling increases; the body is like a water bag, and the stomach resembles a broken vine gourd. Dirt and grease on the skin like ashes and coal, flies and maggots gather messily like sand; in the past you were deceived by your thin skin, now regret the mistake of those former years.

觀膿血想。(3)謂靜觀死人,初爛肉腐成膿, 勢將潰下, 腸胃消糜。當念我風流俊 雅之身, 將來亦必如是, 則婬心淡矣。(1)省庵日: 《風大鼓其内,須礐脹加,身如盛 水袋,腹似斷藤瓜。垢䐣深塗炭,蠅蛆亂聚沙:曾因薄皮註,翻悔昔年差》。

4. Visualize the image of dark reddish juice. [Bu ke de, 4]: Meditate on a putrefying corpse, after it has been lying for a long time, a yellowish liquid flows out, giving off an unbearable stench. You should recollect that your body, with its fragrant and clean skin, in the future will also be like this. Hence lust will fade away. Shengyan [3] stated: Once skin and muscles drop off, the shape is damaged: half-open flesh like a split gourd, a snake trying to burrow out of the intestines. Twined messy hair like withered vines, and rotten clothes like waterfall moss; send a note to the beautiful ladies: do not paint that manure bag.

觀綘汁想。(4)謂靜觀腐爛之屍, 停積既久, 黃水流出, 臭不可聞。當念我肌膚 香潔之身, 將來亦必如是, 則婬心淡矣。(3)省庵日: 《肌膚絻脱落,形質便遭傷:瓜 裂半開肉,蛇鑽欲出腸。枯藤䌂亂髮, 瀑䱦爛衣裳, 寄語嬋娟子: 休將畫粪囊》。

5. Visualize the image of devouring worms. [Bu ke de, 5]: Meditate on a corpse that has been decaying for a long time, worms grow all over the body, they crawl around and gnaw inside the bones, it is like a beehive. You should recollect that the body of your beautiful spouse in the future will also be like this. Hence lust will fade away. Shengyan [6] stated: The corpse is being devoured, a few spots are finished; the hungry belly of a crow does not fill, and it is difficult to dry the saliva of a greedy dog. Back then you loved yourself in vain, who would have pity today? Not equal to pork or lamb meat, [your flesh] may be worth just a few coins. 
觀蟲噉想。(5)謂靜觀積久腐屍, 遍體生蟲, 處處鑽嚙骨節之内, 皆如蜂巢。當 念我鸞儔鳳侣之身，將來亦必如是，則婬心淡矣。(6)省庵日: 《户骸遭噉食,方寸 少完全:不飽飢烏腹,難乾䭒狗涎。當年空自愛,此日有誰憐?不若羊肉,猶堪值幾 錢》。

6. Visualize the image of coiling tendons. [Bu ke de, 6]: Meditate that, when the skin and flesh of a rotten corpse have been gnawed completely, only tendons are left attached to the bones, like ropes binding firewood so that it does not fall apart. You should recollect that your philandering body in the future will also be like this. Hence lust will fade away. Shengyan [5] stated: The thin skin is like torn paper glued together, and the rotten flesh like discarded stale soup; pus and blood break through from within, while flies and maggots fight from outside. By eating pig intestines, it becomes easy to vomit, and dog urine is difficult to wash clean; if not by profound abhorrence, how can you break your delusion?

觀筋維想。(6)謂靜觀腐屍皮肉鑽盡, 止有筋連在骨, 如繩束薪, 得以不散。當 念我偷香蝺玉之身，將來亦必如是，則婬心淡矣。(5)省庵日:《薄皮糊破紙,爛 肉棄陳;膿血從中潰,蠅蛆自外爭。食腸易嘔,洗狗水難清; 不是深憎惡,何由斷妄 情?»。

7. Visualize the image of scattered bones. [Bu ke de, 7]: Meditate on a dead body, once the tendons rot and decay, the bones are scattered crisscrossed, no longer staying in one place. You should recollect that your exalted and precious body in the future will also be like this. Hence lust will fade away. Shengyan [7] stated: The four limbs suddenly divide and scatter, where does a whole body come from? You not only lose your appearance, at the same time your name also becomes empty. As for duration, observe the autumn grass, and in terms of abundance, ask the evening breeze; I request you, Sir, to pay close attention, this matter is detailed and exhaustive.

觀骨散想。(7)謂靜觀死屍, 筋已爛壞, 骨節縱橫, 不在一處。當念我崇高富貴 之身, 將來亦必如是, 則婬心淡矣。(7)省庵日:《四體忽分散,一身何所從?豈唯姿 態失,兼亦姓名空。長短看秋草,穠纖問晚風;請君高著眼,此事細推窮》。

8. Visualize the image of dry bones. [Bu ke de, 9]: Meditate on the abandoned bones in a broken tomb, hit by sun and rain, their color turns white, or yellowish again, trampled by humans and beasts. You should recollect that your body, with its beautiful youth easily fading away, in the future will also be like this. Hence lust will fade away. Shengyan [8] stated: Skin and flesh have melted and disappeared, only the bones remain; rain adds color to moss, water soaks the sand marks. Involving many insects and collecting few descendants, where does passionate love take you to? Feel profound grief for the unreturned soul!

觀枯骨想。(9)謂靜觀破塚棄骨，日暴雨侵，其色轉白，或復黃朽，人獸踐踏。當 念我韶光易邁之身，將來亦必如是，則婬心淡矣。(8)省庵日:《皮肉已銷䤾,唯餘 骨尚存,雨添苔蘚色,水浸土沙痕。牽挽多蟲蟻,收藏少子孫, 風流何處去?愁殺未歸 魂!»。

9. Visualize the image of being burnt. [Bu ke de, 8]: Meditate on a dead body, having been burnt by fire, it is scorched and shrunken on the ground; be it cooked or raw, it is always an unbearable sight. You should recollect that your unparalleled body in the future will also be like this. Hence lust will fade away. Shengyan [9] stated: Raging flames lean on the dry bones, and in a flash, they burn vigorously; red flames in the sky, black smoke on the trees. Be aware that all ends in ashes, and the true mind that very day is suspended. If you wish to go beyond the samsāra path, you should study this meditation carefully.

觀焚燒想。(8)謂靜觀死屍, 被人所燒, 燋縮在地。或熟或生, 不堪目擊。當念 我文章蓋世之身, 將來或亦如是, 則婬心淡矣。(9)省庵日:《烈焰憑枯骨,須臾方 熾然;紅飛天際火,黑透樹頭。忘念同灰盡,真心並日懸,欲超生死路,此觀要精研》. (Tanxuan, 1936, pp. 42-43) 
In this sixth and final part of the essay, Tanxuan's highly scholarly-oriented article finally turns to the actual practice and experience of the aśubha meditation. Though it does not hint at the ways in which Tanxuan himself or his students practiced these teachings, the above explanation of the 'nine meditations' may well have served as meditation guidelines for the same monastics to whom the article was declaredly addressed.

The 'final remarks' of the article consist in a number of new quotations, which deserve close consideration because they allow for a connection between the described practice and the Bodhisattva ideal. The first quotation is taken from another well-known morality book which was promoted by Yinguang. Penned by the Qing dynasty Buddhist layman Zhou Mengyan 周夢顔 (1656-1739, styled Anshi 安士), ${ }^{49}$ it clearly reveals a Mahāyāna concern:

If this visualization is accomplished, it will remove the very root of sensual desire (aiyin 愛媱). I vow that in my future existence I will sweep away the armies of Māra, and that, transforming the body in unmeasurable Buddha kṣetras, I will broadly benefit all sentient beings.

此觀得成就。拔去愛婬根。誓於未來世。掃盡魔王軍。分身無量刹。普利諸有 情。(Zhou Anshi, quoted in Tanxuan, 1936, p. 43)

This is followed by a quotation from the 'Scripture on the Secrets of Meditation' promising rebirth in the heaven of the future Buddha Maitreya. Rebirth in Maitreya's heaven is a typical feature of fifth century meditation manuals, as has been recently demonstrated by Eric M. Greene, ${ }^{50}$ and its appearance here may also be related to the cult of Maitreya followed by Taixu and his disciples (Ritzinger 2017a). The quotation ends with the following words:

Furthermore, one who fixes his thoughts and carefully contemplates, and then comes to see, all the white bones of his body, will at the end of his life be reborn in the Tusita heaven where he will meet Maitreya (tr. Greene 2021b, p. 169).

若復有人, 繫念諦觀, 見舉身白骨。此人命終, 生兒率陀天, 見彌勒佛。( $T$ no. 613: 254c10-11, quoted in Tanxuan, 1936, p. 43) ${ }^{51}$

Finally, after a few canonical verses reiterating the value of this practice for countering sensual desire, ${ }^{52}$ Tanxuan provides a list of the relevant canonical sources, including reference to the chapters (juan 卷) where the practice is presented. ${ }^{53}$ This table of references is worthy of mention as a reminder of the sources available for this practice in the 1930s (see Appendix A).

As we have seen, Tanxuan gives large quotations of a great variety of texts in the main body of the article. These and a number of other scriptures are referenced in the final table. Among Tanxuan's primary sources are meditation manuals, such as the 'Scripture on the Methods of Censuring Sexual Desire' (Chanyao heyu jing 禪要訶欲經, T no. 609, juan 1), a locus classicus for this practice, and other meditation manuals of the fifth century. ${ }^{54}$ Early Buddhist texts include Āgamas and a variety of vinaya literature, including the Shanjianlü piposha 善見律毘婆沙, referenced as a translation from the Pāli. ${ }^{55}$ Quotations from Mahāyāna sūtras are from the Prajñāpāramitā corpus and a few other texts. Śāstra references span from the Sarvāstivāda Abhidharma ${ }^{56}$ to the Srāvakabhūmi ${ }^{57}$ and the Dazhidu lun. ${ }^{58}$ As for tantric texts, Tanxuan particularly quotes a commentary on the Vairocanābhisambodhitantra. ${ }^{59}$ In general, canonical sources of works by Chinese masters are quoted without referencing them, as in the notable case of Zhiyi's works on meditation. ${ }^{60}$

This detailed list of references seemingly aims at giving full legitimacy to the aśubha meditation from the perspective of the Buddhist tradition as a whole.

\section{Final Remarks}

The rediscovery of the aśubha meditation, together with other early meditation techniques, has been presented in this article as both a result and a sign of the spread of modernist ideas into China. In these final remarks I will try to elucidate how and to what extent the analytical category 'Buddhist modernism' may be useful in capturing the 
phenomenon under discussion. ${ }^{61}$ I will mainly refer to Tanxuan's essay, as it offers both an overview and a close look into some of the relevant features of the rediscovery of the visualization of the impure in modern China.

The most common themes developed by the various forms of Buddhist modernisms include the adoption of a text-oriented approach and a modern notion of Buddhism as a world religion, the search for a 'pure' and 'original' Buddhism, an emphasis on meditation, discourses on gender equality, and the establishment of modern forms of education for the Buddhist clergy. ${ }^{62}$ Tanxuan's long essay reveals traces of all the mentioned modernist aspects. A disciple of Taixu, Tanxuan was a modern scholar monk with an interest in 'forgotten' teachings and practices and with a marked preference for a textoriented approach. Not only does his article reveal a rediscovery of early texts within the Buddhist Canon, it also includes a wide array of scriptures, striking us as a true example of the modern monastic education propagated by Taixu and his fellow monks, which by itself reveals an understanding of Buddhism as a world religion. The numerous sources he is able to quote represent all of the main genres present in the Buddhist Canon, because, as he declares himself, 'the visualization of the impure is discussed in detail in both Hinnayāna and Mahāyāna sūtras, vinayas, and śāstras, ${ }^{\prime 63}$ ranging from Āgamas to Tantras. Tanxuan's modernity also emerges through other aspects. First, it is interesting to note that he shows an awareness - even if only a modicum - of gender distinctions, separately addressing female practitioners, at a time when gender had become 'a useful category' in Chinese religions (Valussi 2019). Finally, and more significantly, Tanxuan, who was himself engaged in the revival of the so-called 'Tang Tantrism' (Tangmi 唐密), gives us an idea of the varieties of the visualization of the impure as practiced during his time, when different traditions within the early meditation practices were being revived-marking a new trend in modern Tiantai and Yogācāra approaches to meditation - and new ones were spreading in response to the surge of interest in Japanese and Tibetan tantrism. This latter aspect reflects a modern understanding of Buddhism as a world religion, which favored both the acceptance of other forms of Buddhist practice and the integration of early forgotten teachings in the bosom of the Chinese Mahāyāna.

However, it is my conviction that to fully understand modern forms of Buddhism, one should not only focus on the novel modernist themes resulting from the encounter with Western modernities; rather one should also consider the resilience and vitality of 'concomitant religious phenomena centered on local and long-established practices, rituals, and ways of relating to Buddhist scriptures' (Bianchi and Campo forthcoming). In Tanxuan's essay, we find traces also of this more local approach, such as in the reference to morality books or other pre-modern Chinese materials. It is particularly in these quotations and references that Tanxuan reveals an interest which goes beyond a mere scholarly approach. On the contrary, he strikes us as a sincere promoter of the actual practice of the visualization of the impure, particularly addressing his essay to 'those who leave home to pursue the path,' as he clarifies from the very incipit of his text. From this perspective, what might otherwise seem like a mere display of erudition serves the objective of legitimizing a form of practice that the contemporary sangha may not always be in favor of.

On a general note, distinguishing the masters interested in aśubha meditation according to their doctrinal inclinations and predilections enables us to observe how, within a general modern trend of re-evaluating the whole range of Buddhist teachings, different approaches emerged where modern themes coexisted with more conservative or local inclinations. Notably, Tiantai masters mainly referred to Zhiyi's works (whose main canonical source is the Dazhidu lun) or to later Tiantai-related materials. By contrast, other masters, displaying a more markedly 'modernist' attitude, preferred to turn to texts with Indian origins, and masters interested in tantric Buddhism also referred to tantric scriptures and traditions. ${ }^{64}$ The shared feature of the rediscovery of the aśubha meditation, at least in the cases presented above, seems to be that the visualization of the impure was framed within a Mahāyanna context. Ultimately, as it was for Taixu, the meditation on impurity was implemented as 
'one of the practices common to the three vehicles,' and as such it was legitimized for the modern Chinese Buddhist practitioners.

Funding: This research received no external funding.

Institutional Review Board Statement: Not applicable.

Informed Consent Statement: Not applicable.

Data Availability Statement: Not applicable.

Conflicts of Interest: The author declares no conflict of interest.

\section{Abbreviations}

T Taishō shinshū daizōkyō 大正新修大經. 85 vols., eds. Junjirō Takakusu 高楠順次郎 and Kaigyoku Watanabe渡邊海旭. Tokyo: Taishō Issaikyō Kankōkai, 1924-1934.

X Shinsan Dai Nihon zoku zōkyō 凹新纂大日本續藏經. Tōkyō: Kokusho Kankōkai, 1975-1989 (CBETA edition).

\section{Appendix A. Tanxuan's Sources}

\section{Meditation Manuals}

'Scripture on the Methods of Censuring Sexual Desire' (Chanyao heyu jing 禪要訶欲經, $T$ no. 609 , juan 1);

'Scripture on the Secret Essential Methods of Meditation' (Chan miyao fa jing 禪祕要法經, T no. 613, juan 2);

'Secret Methods for Curing Meditation Sickness' (Zhi chanbing miyaofa 治禪病祕要法, $T$ no. 620$)$;

'Ocean Samādhi Contemplation Scripture' (Guanfo sanmei hai jing 觀佛三昧海經, T no. 643 , juan 9).

\section{Vinaya}

Vinaya of the Mahīsaāsaka (Wufenlü 五分律, T no. 1421, juan 8);

Vinaya of the Sarvāstivāda (Sapoduo lü 薩婆多律, T no. 1435, juan 3);

Shanjianlü piposha 善見律昆婆沙 (T no. 1462, juan 10);

'Sūtra of Mahāprajāpatī' (Daaidao jing 大愛道經, $T$ no. 1478).

III. Early Buddhist Texts

Madhyamāgama (Zhong Ahan jing 中阿含經, $T$ no. 36, juan 20); ${ }^{65}$

'Sūtra of the Collection of the Past Activities of the Buddha' (Fo benxingji jing 佛本行集 經, Sk. Buddhacarita samgrāha, juan 36, T no. 190);

Fenbie gongde lun 分別功德論 (T no. 1507). 
IV. Mahāyāna Sūtras

Ratnakūtasūtra (Baoji jing 寶積經, $T$ no. 310, juan 105); ${ }^{66}$

'Contemplation on the Mind Ground Sūtra' (Xindi guan jing心地觀經, T no. 159, juan 6$),{ }^{67}$

Mahāprajūāpāramitāsūtra (both the Da bore jing 大般若經, $T$ no. 220, and Dapin bore jing 大品般若經, T no. 223, juan 6);

'Great Collection Sūtra' (Daji jing 大集經, $T$ no. 397, juan 243); ${ }^{68}$

'Sūtra of Mañjuśrî's Questions' (Wenshu wen jing 文殊問經, $T$ no. 468);

Śūramgamasūtra (Lengyanjing 楞嚴經, T no. 945).

\section{Tantric Texts}

'Dhāraṇ̄ of the Greatly Powerful One' (Daweide tuoluoni jing 大威德陀羅尼經, T no. 1341);

'Commentary on the Vairocanābhisambodhitantra' (Darijing shu 大日經疏, T no. 1796, juan 20).

\section{VI. Śāstras}

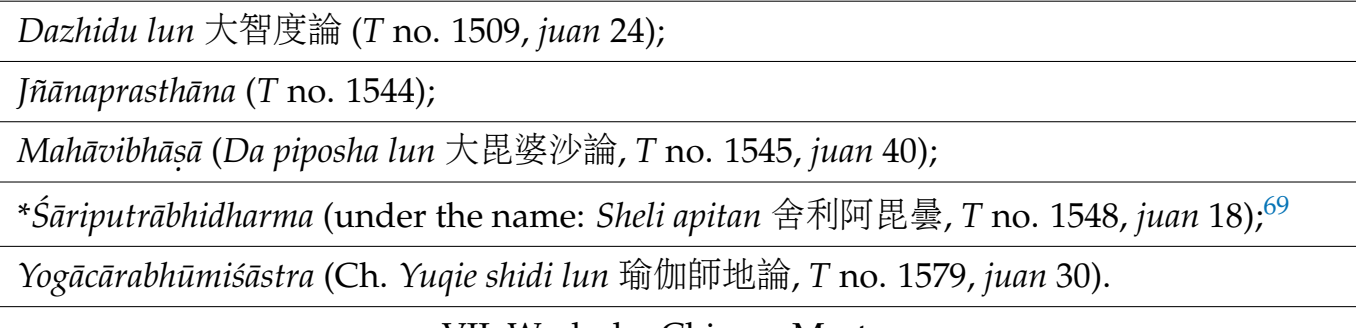

\section{Works by Chinese Masters}

'Commentary on the Flower Ornament Sūtra' (Huayanjing shu 華嚴經疏, T no. 1735, juan 18), by Chengguan 澄觀, 70

'Methods for the Cultivation of a Clear Faith [in the Mahāyāna]' (Jingxin jie guan fa 淨心 戒觀法, T no. 1893), by Daoxuan 道宣; ${ }^{71}$

'Exposition on the Perfection of Dhyāna' (Shi chan boluomi cidi famen 釋禪波羅蜜次第法 門, T no. 1916), by Zhiyi 智顗;

'Four sites for recollection' (Si nianchu 四念處, T no. 1918), by Zhiyi 智顗;

'Treatise on Ten Doubts about Pure Land' (Jingtu shiyi lun 淨土十疑論, T no. 1961), by Zhiyi 智顗. ${ }^{72}$

\section{Notes}

I will engage with the meaning of Buddhist modernism in the context under discussion in the final remarks.

2 I wish to thank Michel Mohr for inviting me to contribute to this special issue on "Impurity Revisited: Contemplative Practices, Textual Sources, and Visual Representations in Asian Religions" and for his support and valuable suggestions. I am also indebted to an anonymous reviewer for the insightful criticism and useful proposals.

3 The present article includes only a brief outline of the general background in which the rediscovery of bujing guan transpired. For a presentation on the phenomenon of the rediscovery of early meditation techniques in modern Chinese Buddhism, see Bianchi (forthcoming).

4 On the use of Hīnayāna, Pāli Buddhism, South, and South-East Asian Buddhism or Southern Buddhism, Śrāvakayāna, and other expressions as alternatives to Theravāda, see Anālayo (2003, pp. 223-28). On the corresponding Chinese terminology, with a focus on modernity, see Bianchi (forthcoming).

5 This 'Hīnayāna' literature was preserved in the Chinese Buddhist canon but was previously regarded as inferior and had been classified at the bottom of the panjiao 判教 systems since the Sui and Tang dynasties. On the rediscovery of the Āgamas by modern Chinese Buddhists, see Travagnin and Anālayo (2020). 
6 The Yogāāărabhūmi itself was reevaluated in modern China and considered a scripture representing the 'original' Mahāyāna. For more information on the role of the Yogācāra tradition within recent developments in Chinese Buddhism, see Makeham (2014). For further details about the importance of the Yogācārabhūmi in twentieth-century Chinese scholastic Buddhism, see Aviv (2013).

7 The 'Treatise on the Path to Liberation' (Jietuo daolun 解脱道論, Pāli *Vimuttimagga; T no. 1648, Chinese translation attributed to Samghabhara/Samghapāla, early sixth c.), one of very few extant Chinese translations of Pāli works, was also 'rediscovered.' Since the comparable Visuddhimagga would not be translated into Chinese until 1981 (Ye, 1981), this text was regarded as the main reference for early meditation techniques within the Theravāda tradition during the Republican era. Awareness of the existence of this text was stimulated in Japan by articles published by the scholar Nagai Makoto (1881-1970). See Jaffe (2019, pp. 211-35). In China, lay-Buddhist scholar Lü Cheng 呂溦 (1896-1989) determined that the *Vimuttimagga was one of the few texts of the Southern traditions to reach China and suggested that the Visuddhimagga was based on this earlier text (Lü 1996). For an overview on the *Vimuttimagga, see Crosby (1999). For a comparison with the Visuddhimagga, see Anālayo (2009). The *Vimuttimagga is not treated in the present study, as I found no evidence of any modern master referring to it for the visualization of the impure in the material I was able to collect.

$8 \quad$ See Taixu (1943), quoted in Wang (2009, p. 158). On the Shi chan boluomi cidi famen, see Greene (2021a, p. 114f) and Wang (2001). In the present study, the term chan 禪 (Sk. dhyāna) is mainly employed to refer to forms of meditation predating the emergence of Chan Buddhism. The latter will only be addressed occasionally, when referring to the Chan school itself or to the form of meditation developed by the Chan masters, i.e. the so-called 'patriarchal chan' (zushichan 祖師禪) mentioned by Taixu (see below, note 15).

9 The other gates include love meditation ( $c i b e i$ 慈悲, Sk. maitrī) for those who are inclined to anger; meditation on causes and conditions (yinyuan 因緣, Sk. pratītyasamutpāda) for those who are inclined to ignorance; meditation on worldly discrimination (jiefenbie 界分別, Sk. dhätuprabheda) for those who are inclined to pride; and breath mindfulness (nian anban 念安般 or nianxi 念息, Sk. ānāpānasmrti) for those who are inclined to discursive thinking. In some cases, such as Kumārajīva's 'Meditation Scripture' (T no. 614) the fourth gate is supplemented by Buddha recollection (nianfo 念佛, Sk. buddhānusmrti), for 'those with equally distributed defilements or grave sins.' See Greene (2021b, pp. 21-22).

10 They involve the visualization of the body (guan shen 觀身), of sensation (guan shou 觀受), of the mind (guan xin 觀心), and of mental formations or dharmas (guan fa 觀法). For a history of this meditation technique based on Pāli, Chinese, and Sanskrit sources, and considering both Hīnayāna/Śrāvakayāna and Mahāyāna texts, see Schmithausen (1976); refer also to Anālayo (2003), Lin (1949), and Stuart (2015).

11 Eric M. Greene $(2016,2021$ ) argues that the term 'visualization' may not fully capture the phenomenology of these practices: 'visualization, a concept coined in the nineteenth century by experimental psychologists, implies a degree of willful control that is usually inappropriate in the context of the visionary experiences aimed for in medieval Chinese Buddhist meditation practices' (Greene 2021a, p. 94, note 67). More specifically, Green notices that the object to be 'visualized' should not be seen as a mental representation phenomenologically corresponding to ordinary sight; in addition, he observes that these practices result in confirmatory experiences that can be better understood as 'visions' rather than visualizations. This notwithstanding, in the present study I have followed the convention of translating guan 觀 as 'visualization,' by which I imply the imaginatory observation of the described object (the decaying corpse) by the practitioner. I only occasionally touch upon confirmatory visions.

12 Particularly, the 'Special Issue on Impurity Revisited' (Religion, 11 and 12), includes contributions addressing Chinese Buddhism or Chinese materials by Dhammajoti (2021), Kritzer (2020), and Mohr (2020). For the meditation on impurity in Chinese Buddhist texts, see also Greene (2006, 2014, 2016, and the two recent monographies, Greene 2021a, 2021b) and Radich (2019). General descriptions of aśubha meditation are provided by Dhammajoti (2009) and, with reference to the Pāli Satipatțhāna, Anālayo (2003, pp. 152-55). For the practice in Theravāda Buddhism, see also Bond (1980). For the Gandhāran early Yogācāra context, see Stuart (2015, vol. 1, pp. 505-8). For the Khotanese Mahāyāna context, see Martini (2011).

13 The practice of bujing guan by Chinese Buddhists during and after the Song dynasty is a topic that deserves further investigation. Among the texts where it is explained are the following: X no. 976 (Song), X no. 250 (Yuan), X no. 0877 (Yuan), $T$ no. 1939 (Ming), X no. 1162 (Ming), X no. 1549 (Qing), etc. Significantly, many of these texts are related to the Tiantai tradition.

For the interfusion of Mahāyāna elements with the Abhidharma interpretation of the visualization of the impure in the 'Ocean Samādhi Contemplation Scripture' (T no. 643) and the 'Meditation Sūtra of Dharmatrāta' (T no. 618), showing an increasing interest in Buddha visualizations, see Dhammajoti (2021, pp. 23-30). Also notice that, in the 'Meditation Sūtra of Dharmatrāta' (Damoduoluo chanjing 達摩多羅禪經, T no. 618), the visualization of the impure culminates in visions of a pure land, which can be associated with the Mahāyāna (Mohr 2006, 2020). Kumārajīva's 'Meditation Scripture' (T no. 614) describes all practices, including the visualization of impurity, within the paths for becoming an Arhat, a Pratyekabuddha, or a Buddha; despite the differences in the final goals, the Bodhisattva methods are very similar to those of the non-Bodhisattva practitioners (Yamabe and Sueki 2009, pp. XIV-XVIII). For the absence of a clearly marked dichotomy between Hīnayāna and Mahāyāna methods in the early meditation manuals, see Greene (2021b, pp. 25-28).

Taixu distinguishes between meditation in China before the development of Chan and the features of meditation as practiced by Chan Buddhism. The former includes 'breath meditation' (anbanchan 安般禪), the 'five gates of meditation' (wu menchan, or 
wu tingchan), 'meditation of being mindful of the Buddha' (nianfochan 念佛禪) and 'meditation on the real characteristics of things' (shixiangchan 實相禪). This essay was recorded by Taixu's disciples and published as part of the collection Zhongguo foxue 中國佛學 (Taixu, 1943). According to Yinshun, Taixu first realized the importance of meditation as the very feature of Chinese Buddhism in 1926 (Yinshun, 1973, p. 217a).

More precisely, the recollection of the body is related to impurity (guan shen bujing 觀身不淨), that of the sensation to suffering (guan shou shiku 觀受是苦), that of the mind to impermanence (guan xin wuchang 觀心無常), and that of mental formations or dharmas to the no-self (guan fa wuwo 觀法無我).

In the version mentioned by Taixu, the thirty-seven practices for the attainment of enlightenment are as follows: 'four sites for recollection;' 'four kinds of right effort' (si zhengqin 四正勤); 'four supernatural powers' (si ruyi zu 四如意足); 'five wholesome roots' (wugen 五根); 'five powers' (wuli 五力); ‘seven branches of bodhi' (qi juezhi 七覺支); and 'eightfold holy path' (ba shengxing 八聖行).

18 Translated by An Shigao 安世高 (148-170), this scripture is focused on eight forms of mindfulness, which are related to the eightfold path.

The lecture was delivered at the Yongning monastery 永寧寺 in Zhenhai (see Taixu, 1934).

The lecture was delivered at the Minnan Buddhist Academy (see Taixu, 1932). The 'Mahāyāna Sūtra on visualization of the mind ground of essential nature' (Dasheng bensheng xindi guan jing 大乘本生心地觀經, T no. 159), a probable apocryphal scripture attributed to Prajn̄ā (late eighth c.), includes many meditation practices for monastics.

In later times, another Tiantai master, Miaojing 竗境 (1930-2003), recommended the visualization of the impure as part of the 'contemplation of the body' within the 'four sites for recollection' (Miaojing, 2006). 'In the later decades of his teaching career, Miaojing put much energy into teaching this meditation method [si nianchu], with special focus on the initial element of the fourfold guan procedure, in which a vivid set of white skeleton contemplations is carried out. When a meditator has become securely proficient in this method, then other guan practices can be adopted, as suitable for the individual practitioner' (Birnbaum 2019).

Examining the phases of decaying involves looking at how various 'ideations' (xiang 想, Sk. samjūa $)$ produce corresponding 'signs' (xiang 相, Sk. lakșana). This may constitute one of the keys for understanding the link between samjiñ $\bar{a}$ (ideations, conceptions), lakșana (signs, marks), and ākāra (images). I am grateful to Michel Mohr for this insightful suggestion. Also see Mohr (2020, p. 19).

The Mahāprajūāpāramitāsūtra 'offers one of the earliest enumerations of the nine perceptions of foulness, that is the nine stages through which a dead body transforms until cremated' (Mohr 2009, p. 177). The sequence goes as follows: 1. 'Swelling and tumefaction' (pangzhang xiang 膖脹想), 2. ‘Pus and decomposition' (nonglan xiang 膿爛想), 3. 'Extraordinary red color' (yichi xiang 異赤想), 4. 'Bluish stasis of blood' (qingyu xiang 青疙想), 5. ‘Being devoured' (zhuodan xiang 啄噉想), 6. 'Being scattered' (lisan xiang 離散想), 7. ‘Skeleton bones' (shigu xiang 骸骨想), 8. ‘Being burnt' (fenshao xiang 焚燒想), and 9. ‘Decaying' (miehuai xiang 滅壞想).

The list in the Yogācārabhūmi reads: 1. 'Bluish stasis of blood' (qingyu xiang), 2. 'Pus and decomposition' (nonglan xiang), 3. 'Decaying' (pohuai xiang 破壞想), 4. 'Swelling and tumefaction' (pangzhang xiang), 5. 'Being devoured' (danshi xiang 噉食 想), 6. 'Besmearing of blood' (xuetu xiang 血塗想), 7. 'Scattering' (lisan xiang 離散想), 8. 'Bones' (gusuo xiang 骨鎖想), and 9. 'Observation of emptiness' (guancha kong xiang 觀察空想).

The 'Meditation Scripture' has the following sequence: 1. 'Bluish stasis of blood' (qingyu 青瘀), 2. 'Swelling and tumefaction' (pangzhang 膖脹), 3. 'Decomposition' (polan 破爛), 4. 'Blood shedding' (xueliu 血流), 5. 'Besmearing [of blood]' (tuman 塗漫), 6. 'Stinking pus' (chounong 臭膿), 7. 'Being devoured but not completely' (danshi bujin 噉食不盡), 8. 'Scattering of the bones' (gusan骨散), and 9. 'Scorched' (shaojiao 燒焦). For an English translation, see Yamabe and Sueki (2009, p. 11). On the 'Meditation Scripture,' see also Greene (2021a).

In the 'Exposition on the Perfection of Dhyāna,' Zhiyi's sequence reads as follows: 1. 'Swelling' (zhang xiang 脹想); 2. 'Decaying' (huai xiang 壞想); 3. ‘Besmearing of blood' (xuetuman xiang 血塗漫想), 4. 'Pus and decomposition' (nonglan xiang), 5. 'Bluish stasis of blood' (qingyu xiang), 6. ‘Being devoured' (han xiang 噉想), 7. 'Scattering' (san xiang 散想), 8. ‘Bones' (gu xiang 骨想), and 9. 'Burning' (shao xiang 燒想). The same list is also included in the Mohe zhiguan 摩訶止觀 (T no. 1911, 121c15-16).

For a study on Dokuan Genkô 獨庵玄光 (1630-1698)'s 'Odes on the Nine Perceptions' and in general for the sources and meaning of this sequence, see Mohr (2009).

Shengyan's text is still often quoted on contemporary Buddhist websites. e.g., http://www.suttaworld.org/ancient_t/ascs/3-5. htm (accessed on 4 October 2021); http:/ / fodizi.net/qt/ qita/16591.html (accessed on 4 October 2021); etc. On Yinguang's talents in revising, editing and promoting morality books, see Kiely (2016, p. 34f).

Examples of the contemporary spread of Yinguang's version—in its original form or translated into modern Chinese-on Buddhist websites include: http:/ / foxuege.com/2019/09/26 (accessed on 4 October 2021); http://big5.xuefo.net/nr/article21/ 212449.html (accessed on 4 October 2021); http:/ / www.bskk.me/thread-3152704-1-1.html?bovqzc=xtiy (accessed on 4 October 2021); https:/ / www.guang5.com/fjrw/hcrw/yinguangdashi/170883.html (accessed on 4 October 2021); etc. 
See Nenghai (1946). The texts are newly translated for the purpose of this study. An earlier English translation of Nenghai's meditation techniques is included in Bianchi (2001, pp. 136-65).

The explanation was recorded by Nenghai's nun disciple Longlian 隆蓮 (1909-2006) on the basis of Nenghai's lectures and was later revised by Nenghai himself. On the subject of meditation, Nenghai referred to Tsongkhapa's Lamrim as well as to a number of Chinese scriptures, including the 'Meditation scripture.' In his later years he focused on the *Śäriputrābhidharma (Shelifu apitan lun 舍利弗阿毗曇論, T no. 1548, 620-624), a systematic overview of meditation techniques; Nenghai's lectures were centered on the chapter on Dhyāna (Chanding pin 禪定品). See Nenghai (1960a, 1960b).

Tanxuan went to Japan to study esoteric Buddhism (Shingon and Tendai) in 1925 and returned to China in 1929-1930; he studied in Japan again between 1934-1935. He was an expert on Tendai and returned to China with more than two thousand esoteric Buddhist scriptures. See Chen (2008, p. 392).

The quotation, on the impurity of one's own body, however, is not from the Prajñāāaramitāsūtra but from the 'Contemplation on the Mind Ground Sūtra' (T no. 159: 321b14-16). I was not able to trace the following quotation about the visualization of one's own body mentioned by Tanxuan (1936, p. 37) as taken from the Prajñāpāramitāsūtra.

The first quotation, from the Dazhidu lun, is not verbatim. This is followed by a quotation on the filthy aspects of the body ( $T$ no. 1509: 60a21, almost verbatim) and on the five types of impurity ( $T$ no. 1509: 198c, 22-24).

$T$ no. 1545: 840a26-b10 ( ${ }^{*}$ Mahāovibhāsāa, see note 41 below). At this point Tanxuan also quotes the 'Sūtra of Mañjuśrís Questions' (Wenshu wen jing 文殊問經, $T$ no. 468), which explains that the visualization of impurity is aimed at getting rid of desire. However, I was not able to trace the exact quotation.

On these two forms of the visualization of impurity, i.e., the contemplation of the impurities of a living human body and the meditation on the decay of a corpse—a standard Sarvāstivāda systematization—see Dhammajoti (2009) and Greene (2006, pp. 66-92).

Quotations include the 'Ocean Samādhi Contemplation Scripture' (T no. 643: 652b), which is paraphrased instead of being quoted at length (on this text, which is currently regarded as apocryphal, see Yamabe 1999) and the Jñ̄anaprasthāna (by quoting its commentary ${ }^{*}$ Mahāovibhāsā, $T$ no. 1545: 206c27-207a26), where the Buddha declares that he will devote himself to the visualization of impurity.

Quotation on the Buddha teaching the practice, the monks being scared, fetching a corpse, being scolded by the laypeople, and lastly, the Buddha explaining that they should not touch a corpse (T no. 1421: 134b15-18, b21-24, and b28-c04).

On this early Chinese Commentary on the Ekōttarāgama, which shows an affinity with Prajñāpāramitā thought, see Palumbo (2013).

The 'Treatise of the Great Commentary on the Abhidharma' (Sk. *Abhidharmamahāvibhāsāsas̄āstra, T no. 1545.27: 1a-1004a) is a commentary on the Jñannaprasthāna (T no. 1544), a canonical work of the Sarvāstivāda school. On the aśubhabhāvanā in the Mahāoibhāșā, see Dhammajoti (2009). The text quoted is the Jingxin jie guan fa 淨心戒觀法 ( $T$ no. 1893).

A reference to the Daweide tuoluoni jing 大威德陀羅尼經 (T no. 1341), quoted from the Fayuanzhulin 法苑珠林 (T no. 2122: 446b26-446c05).

The content seems to be an abridged version of the Zhi chanbing miyaofa 治禪病祕要法 (T no. 620: 335c09f). It may also be a quotation taken from another non-canonical meditation manual. On this genre and on the various 'Chan essentials,' see Greene (2021b, pp. 80-81). Tanxuan apparently quotes the text from the Fayuanzhulin (T no. 2122: 630c04-11).

In this case the text is very likely taken from the Zhi chanbing miyaofa ( $T$ no. 620$)$, even if minor variations may point to a different version than that from the Taishō text. This is a possible reference to a tantric version of the practice, whereby the syllable $r a$ is connected with the fire element. Quotations inspired by the Bu ke le are presented in full, Shengyan's verses in quotation marks. Due to the need to match their contents, both sequences are slightly modified in Taoxuan's combination.

The text, titled Yuhai hui kuang 欲海回狂, is the third chapter of the 'Anshi collection' (Anshi quanshu 安士全書), which became well known at the beginning of the twentieth century as it was promoted as the number one 'moral book' (shanshu 善書) by Yinguang. See Kiely (2016, p. 34).

The text broadly corresponds to the Chan miyao fa jing 禪祕要法經 ( $T$ no. 613: 254c03-11), a prominent example of the fifthcentury meditation manuals attributed to Kumārajīva. Also in this case, as with above, it may be that the quotation is taken from a non-canonical version of the meditation manual. On T no. 613, see Greene (2018), and for the rebirth in Maitreya's heaven, see Greene (2021b, pp. 12-13).

Small differences between Tanxuan's text and the Taishō edition in italics.

The verses are quoted verbatim from the 'Sūtra of the Collection of the Past Activities of the Buddha' (Fo benxingii jing 佛本行集 經, Sk. Buddhacaritasamgrāha, T no. 190: 729a08-11). Tanxuan, however, references the Mahāvibhāșā. Translated by Jñānagupta, the Buddhacaritasamgräha is the most complete version of the Buddha's life in the Chinese canon. Tanxuan includes this text in the final list of references. 
See Tanxuan (1936, pp. 43-44). For an overview of sources on the meditation on impurity-ranging from Pāli texts, Chinese Āgamas, Northern Abhidharma tradition and Yogācāra tradition, to the meditation manuals—see Dhammajoti $(2009,2021)$. The list includes the 'Secret Methods for Curing Meditation Sickness' (Zhi chanbing miyaofa 治禪病祕要法, T no. 620), one of the apocryphal meditation manuals of the fifth century, describing a series of healing meditations. See Greene (2021b, p. 75f).

The Shanjianlü piposha (tr. attributed to Samghabhadra, 488) is a vinaya commentary which was considered a translation of the Samantapāsādik $\bar{a}$ (a commentary attributed to Buddhaghoșa) throughout the twentieth century. This attribution has been questioned by scholars. See Heirman (2004) and, for the origin of this attribution by Takakusu Junjirō (1866-1945), Jaffe (2019, p. 218). It is referenced by Tanxuan as a translation from the Pāli ( $T$ no. 1462: 744b11-14 and b28-c01).

The Jñanaprasthāna (T no. 1544) and its commentary *Mahāvibhāșā (T no. 1545). See note 41. For the visualization of impurity in the Sarvāstivāda Abhidharma, see Dhammajoti (2009, pp. 248-63).

Referenced under the general title of Yogācārabhümi-šasstra (Ch. Yuqie shidi lun 瑜伽師地論, T no. 1579, 30: 452a11f).

The Dazhidu lun is quoted various times in the text.

The Darijing shu 大日經疏 (T no. 1796, juan 20), by Yixing 一行 (683-727), a central text for the Japanese Shingon school.

The 'Four sites for recollection' (T no. 1918), 'Exposition on the Perfection of Dhyāna' (T no. 1916) and 'Treatise on Ten Doubts about Pure Land' (T no. 1961), three works by Zhiyi, are quoted verbatim in the main text without explicit reference, and are also not included in the final table. On one occasion, Daoxuan references the Dazhidu lun, but quotes Zhiyi's own quotation of the text (T no. 1918: 559a01-2).

61 The notion of 'Buddhist modernism' is used to refer to forms of Buddhism that developed in the nineteenth century and afterward as a response (and reaction) to the spread of ideas drawn from Western modernity (McMahan 2008). Recent scholarship has shown that one should rather speak of 'modernisms,' given the variety of aspects involved, and considering the fact that local developments may include only a few of them depending on contingent factors and on the local understanding of 'modernity' (see the essays included in McMahan 2012); for the Chinese case, see Fisher (2012); Ritzinger (2017b). While often employed as interchangeable synonyms, I prefer to distinguish Buddhist modernism from the broader category of 'modern Buddhism,' which includes a combination of these modernist approaches and more established teachings and practices.

62 Among the other most common themes is also the adoption of a modern scientific approach and of the new category of religion as opposed to superstition; 'modernist' features also include an emphasis on rationality, on egalitarianism in general, and on a social and/or political engagement of the Buddhist clergy, as well as an increased involvement of the laity and a connection with nationalism, etc. On the focus on meditation, see McMahan and Braun (2017). On the spread of the notion of 'original Buddhism' in Republican China, see Ritzinger (2016). 不淨觀,在大小乘經律論,皆有詳論 (Tanxuan, 1936, p. 43).

64 The case of Nenghai shows how the boundaries between these categories should not be perceived as too strict, as he was both responding to the urge to reestablish a tantric tradition in China and behaving as a Buddhist modernist trying to recover early forgotten practices.

65 Only mentioned in the final list.

66 Only mentioned in the final list.

67 Quoted in the main text without explicit reference, but mentioned in the final list.

68 Only mentioned in the final list.

69 Only mentioned in the final list.

70 Only mentioned in the final list.

71 Daoxuan's text is quoted in the main text without explicit reference, though it is mentioned in the final list.

72 The three texts by Zhiyi are quoted in the main text without explicit reference, and are also not mentioned in the final list.

\section{References}

\section{Primary Sources}

Daqu 答劬. 1936. “Fojiao de bujing guan” 佛教的不淨觀. Renjianjue 人間覺 1: 6-8.

Fazhi 法智. 1938. “Bujing guan jiu xiang guan cidi song” 不淨觀九想觀次第頌. Haichaoyin 海潮音 19: 49-50.

Miaojing 竗境. 2006. Si nianzhu jiangji 四念住講記. Taipei and Vadito NM: Meiguo Fayunsi chubanshe. Available online: http: // www.book853.com/show.aspx?id=1626\&cid=12 (accessed on 4 October 2021).

Nenghai 能海. 1946. Sanguiyi guan chuxiu lïefa. Nenghai shangshi chuanshou 三的依觀初修略法. Longlian 隆蓮, ed. Chengdu: Jincisi huguo jingang daochang.

Nenghai 能海. 1960a. Shelifu apitanlun chandingpin xueji 舍利弗阿毗睃論禪定品學記. Reprint: Jiedinghuijiben sanxue 戒定慧基本三學， 215-310. Shanghai: Shanghai foxue shuju, 1996.

Nenghai 能海. 1960b. Shelifu apitanlun chanding pin xueji jianglu 舍利弗阿毗晊論禪定品學記講錄. Longlian 隆蓮, ed. Reprint: Sansue jianglu三學講錄, 278-354. Shanghai: Shanghai foxue shuju, 1997. 
Shengyan 省菴. 1934. “Bujing guan song (bingxu)” 不淨觀頌(並敘). Hunan fojiao jushilin linkan 湖南佛教居士林林刊 16 (12-13). Reprint of $X$ no. 1179 .

Taixu 太虛. 1921. Fosheng zong yao lun (Chunzheng de fofa) 佛乘宗要論（純正的佛法）. Guangzhou: Guangzhou Jiangjinghui 廣州講經 會. Available online: https:/ /book.bfnn.org/books2/1758.htm. (accessed on 4 October 2021).

Taixu 太虛. 1932. Dasheng bensheng xindi guan jing 大乘本生心地觀經. Xiamen: Minnan Buddhist Academy 閩南佛學院. Available online: https:/ / book.bfnn.org/books2/1758.htm. (accessed on 4 October 2021).

Taixu 太虛. 1934. Foshuo ba da ren jue jing jiangji 佛説八大人覺經講記. Luoyang: Yongning monastery 永寧寺. Available online: https:/ /book.bfnn.org/books2/1891.htm. (accessed on 4 October 2021).

Taixu 太虛. 1943. “Zhongguo foxue tezhi zai Chan” 中國佛學特質在禪. Reprint: Chanxue lunwenji 禪學論文集. Ed. Zhang Mantao 張 曼濤. Taipei: Dasheng chubanshe 大乘出版社 1981, 1-29.

Tanxuan 談玄. 1936. “Bujing guan fa” 不淨觀法. Haichaoyin 海潮音 17: 36-44.

Xianming 顯明. 1936. “Bujing guan duizhi tanyu lun” 不淨觀對治貪欲論. Hongfa kan 弘法刊 31: 15-17.

Ye Jun 葉均, tr. 1981. Qingjing daolun 清淨道論, by Jueyin 覺音 (Buddhagoṣa). Beijing: Zhongguo fojiao wenhua yanjiusuo 中國佛教文 化研究所.

Yinguang 印光, ed. 1927. Shou kang bao jian (Ji zengding Bu ke lu) 壽康寶鑑 (即增訂不可錄). Reprint Taibei, Fotuo jiaoyu jijinhui 佛陀教 育基金會, 1999.

Yinshun 印順. 1973. Taixu dashi nianpu 太虛大師年譜. Taipei: Yinshun wenjiao jijinhui 印順文教基金會. Available online: https: / / cbetaonline.dila.edu.tw/zh/Y0013. (accessed on 4 October 2021).

Zhaowu 照悟. 1936. “Duo tan zhongsheng bujing guan” 多貪衆生不淨觀. Hongfa kan 弘法刊 31: 114-15.

Zhou Mengyan 周夢顔, 1898 (reprint). Anshi quanshu 安士全書. Yangzhou: Yangzhou zangjing chanyuan 揚州藏經禪院.

Zhou Shujia 周叔迦. 1943. “Bujing guan” 不淨觀. Huiguang 慧光, ed. Foxue yuekan 佛學月刊 3: 10-11.

\section{Secondary Sources}

Anālayo, Bhikkhu. 2003. Satipațthāna: the Direct Path to Realization. Birmingham: Windhorse.

Anālayo, Bhikkhu. 2009. The Treatise on the Path to Liberation (解脱道論) and the Visuddhimagga. Fuyan Buddhist Studies 4: 1-15.

Aviv, Eyal. 2013. The Root that nourishes the Branches: The Role of the Yogāāarabhūmi in 20th-Century Chinese Scholastic Buddhism. In The Foundation for Yoga Practitioners: The Buddhist Yogāāārabhūmi Treatise and its Adaptation in India, East Asia, and Tibet. Edited by Ulrich Timme Kragh. Cambridge: Harvard University Press, pp. 1078-91.

Bianchi, Ester. 2001. The Iron Statue Monastery. "Tiexiangsi," a Buddhist Nunnery of Tibetan Tradition in Contemporary China. Firenze: Leo S. Olschki.

Bianchi, Ester. Forthcoming. Theravāda Meditation in Modern and Contemporary Chinese Buddhism with a Focus on Mahasati Dynamic Vipassanā in Shifosi 石佛寺, Sichuan. In Metamorphosis in Contemporary Chinese Buddhism. Edited by Zhe Ji, Yoshiko Ashiwa and David Wank.

Bianchi, Ester, and Daniela Campo. Forthcoming. Introduction. In Take the Vinaya as Your Master. Monastic Discipline and Practices in Modern Chinese Buddhism. Edited by Ester Bianchi and Daniela Campo.

Birnbaum, Raoul. 2019. Master Miaojing's Commitment to Education. Paper presented at the AAR 2019 annual meeting, San Diego, CA, USA, November 23-26.

Bond, George D. 1980. Theravada Buddhism's Meditations on Death and the Symbolism of Initiatory Death. History of Religions 19: 237-58. [CrossRef]

Chen, Bing. 2008. The Tantric Revival and Its Reception in Modern China. In Images of Tibet in the 19th and 20th Centuries. Edited by Monica Esposito. Paris: École Française d'Extrême-Orient, pp. 387-427.

Crosby, Kate. 1999. History Versus Modern Myth: The Abhayagirivihāra, the Vimuttimagga and Yogāvacara Meditation. Journal of Indian Philosophy 27: 503-50. [CrossRef]

Dhammajoti, K. L. 2009. The Aśubhā Meditation in the Sarvāstivāda. Journal of the Centre for Buddhist Studies 7: 248-95.

Dhammajoti, K. L. 2021. Meditative Experiences of Impurity and Purity-Further Reflection on the aśubhā Meditation and the śubha-vimokșa. Religions 12: 86. [CrossRef]

Fisher, Garreth. 2012. Buddhism in China and Taiwan. In Buddhism in the Modern World. Edited by David L. McMahan. New York: Routledge, pp. 69-88.

Greene, Eric M. 2006. Of Bones and Buddhas: Contemplation of the Corpse and its Connection to Meditations on Purity as Evidenced by 5th Century Chinese Meditation Manuals. Ph.D. thesis, University of California, Berkeley, CA, USA.

Greene, Eric M. 2014. Healing Breaths and Rotting Bones: On the Relationship between Buddhist and Chinese Meditation Practices during the Eastern Han and Three Kingdoms Period. Journal of Chinese Religions 42: 144-83. [CrossRef]

Greene, Eric M. 2016. Seeing Avijñapti-rūpa-Buddhist Doctrine and Meditative Experience in India and China. In Buddhist Meditative Traditions: Comparison and Dialog (佛教禪修傳統 : 比較與對話). Edited by Kuo-Pin Chuang 莊國涁. Taipei: Dharma Drum Publishing Corporation, pp. 107-70.

Greene, Eric M. 2018. The Authority of Meditation in the Kaiyuan Era-The Scripture on the Secret Essentials of Meditation and the Scripture on the Ten Wheels in Cave 59 at the Wofoyuan. In Buddhist Stone Sütras in China: Sichuan Province. Edited by Martin Bemmann and Sun Hua. Wiesbaden: Harrassowitz, vol. 4, pp. 75-92. 
Greene, Eric M. 2021a. Chan Before Chan. Meditation, Repentance, and Visionary Experience in Chinese Buddhism. Honolulu: University of Hawaii Press.

Greene, Eric M. 2021b. The Secrets of Buddhist Meditation. Visionary Meditation Texts from Early Medieval China. Honolulu: University of Hawaii Press.

Heirman, Ann. 2004. The Chinese Samantapāsādikā and its School Affiliation. Zeitschrift der Deutschen Morgenländischen Gesellschaft 154: 371-96.

Jaffe, Richard M. 2019. Seeking Śäkyamuni. South Asia in the Formation of Modern Japanese Buddhism. Chicago: University of Chicago Press.

Kiely, Jan. 2016. Master Yinguang and His Pure Land Revival Movement. In Making Saints in Modern China. Edited by David Ownby, Vincent Goossaert and Zhe Ji. New York: Oxford University Press, pp. 30-77.

Kritzer, Robert. 2020. Meditation on the Body in Chapter 7 of Saddharmasmrtyupasthānasūtra. Religions 11: 283. [CrossRef]

Lin, Li-kuang. 1949. L'aide-Mémoire de la Vraie Loi (Saddharma-Smrtyupasthāna-Sūtra); Recherches sur un Sūtra Développé du Petit Véhicule. Paris: Adrien-Maisonneuve.

Lü, Cheng 呂澂. 1996. Jietuo daolun fenbie ding pin jiangyao 解脱道論分别定品講要. In Lü Cheng Foxue Lunzhu Xuanji 呂澂佛學論著選 集. Jinan: Jilu Shushe, vol. 2, pp. 1042-67.

Makeham, John, ed. 2014. Transforming Consciousness: Yogācāra Thought in Modern China. Oxford: Oxford University Press.

McMahan, David L. 2008. The Making of Buddhist Modernism. New York and London: Oxford University Press.

McMahan, David L., ed. 2012. Buddhism in the Modern World. New York: Routledge.

McMahan, David L., and Erik Braun. 2017. Meditation, Buddhism, and Science. New York: Oxford University Press.

Martini, Giuliana. 2011. Mahāmaitrī in a Mahāyāna Sūtra in Khotanese-Continuity and Innovation in Buddhist Meditation. Chung-Hwa Buddhist Journal 24: 121-94.

Mohr, Michel. 2006. Imagining Indian Zen: Tōrei's Commentary on the Ta-mo-to-lo ch'an ching and the Rediscovery of Early Meditation Techniques during the Tokugawa Era. In Zen Classics: Formative Texts in the History of Zen Buddhism. Edited by Steven Heine and Dale S. Wright. Oxford: Oxford University Press, pp. 215-46.

Mohr, Michel. 2009. Cutting through Desire: Dokuan Genkō's Odes on the Nine Perceptions of Foulness. The Eastern Buddhist 40: 175-215.

Mohr, Michel. 2020. Advanced Contemplation of the Impure: Reflections on a Capstone Event in the Meditation Sutra. Religions 11: 386. [CrossRef]

Palumbo, Antonello. 2013. An Early Chinese Commentary on the Ekôttarika-āgama: The Fenbie Gongde Lun 分別功德論 and the History of the Translation of the Zengyi Ahan Jing 增壹阿含經. Taipei: Dharma Drum Publishing Corporation.

Radich, Michael. 2019. Reading the Writing on the Wall: 'Sengchou's' Cave at Xiaonanhai, Early Chinese Buddhist Meditation, and Unique Portions of *Dharmakṣema's Mahāparinirvāṇa-mahāsūtra. Journal of the International Association of Buddhist Studies 42: 515-632.

Ritzinger, Justin R. 2016. Original Buddhism and its Discontents: The Chinese Buddhist Exchange Monks and the Search for the Pure Dharma in Ceylon. Journal of Chinese Religions 44: 149-73. [CrossRef]

Ritzinger, Justin R. 2017a. Anarchy in the Pure Land: Reinventing the Cult of Maitreya in Modern Chinese Buddhism. New York: Oxford University Press.

Ritzinger, Justin R. 2017b. Parsing Buddhist Modernity in Republican China. Ten Contrasting Terms. In Buddhist Modernities: Reinventing Tradition in the Globalizing Modern World. Edited by Hanna Havnevik, Ute Hüsken, Mark Teeuwen, Vladimir Tikhonov and Koen Wellens. London and New York: Routledge, pp. 51-65.

Schmithausen, Lambert. 1976. Die vier Konzentrationen der Aufmerksamkei t. Zur geschicht lichen Entwicklung einer spirituellen Praxis des Buddhismus. Zeitschrift für Missionswissenschaft und Religionswissenschaft 60: 241-66.

Stuart, Daniel M. 2015. A Less Traveled Path: Saddharmasmrtyupasthanasutra Chapter 2, Critically Edited with a Study on Its Structure and Significance for the Development of Buddhist Meditation. Wien: Verlag der Österreichischen Akademie der Wissenschaften.

Travagnin, Stefania, and Bhikkhu Anālayo. 2020. The Three-anga Theory in Master Yinshun's 印順 Scholarship: Assessing the State of Āgama Studies in Twentieth-century China. In Research on the Samyukta-āgama. Dharma Drum Institute of Liberal Arts Research Series; Edited by Bhikkhunī Dhammadinnā. Taipei: Dharma Drum Corporation, pp. 933-1007.

Valussi, Elena. 2019. Gender as a Useful Category of Analysis in Chinese Religions-With Two Case Studies from the Republican Period. In Concepts and Methods for the Study of Chinese Religions. Volume III Key Concepts in Practice. Edited by Stefania Travagnin and Paul Katz. München: De Gruyter, pp. 133-67.

Wang, Huei-hsin. 2001. Zhiyi's Interpretation of the Concept “Dhyana” in his Shi Chan Boluomi Sidi Famen. Ph.D. thesis, The University of Arizona, Tucson, ZA, USA.

Wang, Ching-wei. 2009. The Practice of Mahāyāna Si Nianchu in Sixth Century China: Huisi's Interpretation and Practice of Si Nianchu in His Sui Ziyi Sanmei. Chung-Hwa Buddhist Journal 22: 153-78.

Yamabe, Nobuyoshi. 1999. The Sūtra on the Ocean-Like Samādhi of the Visualization of the Buddha: The Interfusion of the Chinese and Indian Cultures in Central Asia as Reflected in a Fifth Century Apocryphal Sūtra. Ph.D. thesis, Yale University, New Haven, CT, USA.

Yamabe, Nobuyoshi, and Fumihiko Sueki, transs. 2009, The Sūtra on the Concentration of Sitting Meditation. Taishō Volume 15, Number 614. Translated from the Chinese of Kumārajīva. Berkeley: Numata Center for Buddhist Translation and Research. 